Images in...

\title{
Porphyria or not porphyria - that is the question...
}

\author{
A Smyth, L Redahan, C Wall, G J Mellotte \\ Department of Nephrology, Adelaide and Meath Hospital, Dublin, Ireland
}

Correspondence to A Smyth, andrewsmyth@physicians.ie

\section{DESCRIPTION}

A 55-year-old man presented with a 2-month history of blisters affecting his hands. His history was significant for treated multiple myeloma with residual monoclonal gammopathy of undetermined significance, and end stage renal disease on automated peritoneal dialysis. Medications included aspirin, clopidogrel, warfarin, pregabalin, bronchodilators and hydrocortisone. Examination showed widespread scarring on the dorsum of the hands with multiple intact fluid filled blisters (figure 1) in a classic distribution for porphyria cutanea tarda (PCT) (figure 2). He was transitioned to intermittent high-flux haemodialysis for other reasons, but coinciding with this change, his blistering rash became significantly worse. Skin biopsy showed mild hyperkeratosis, minimal dermal inflammation and negative direct immunofluorescence. Urine and faecal porphyria screens were negative, thereby excluding PCT and diagnostic of pseudoporphyria. Although aspirin was identified as a possible causative agent, this could not be discontinued due to recent coronary metallic stenting. He was treated with n-acetylcysteine (NAC) $600 \mathrm{mg}$ twice daily for 2 months with advice on minimising sun exposure. His rash improved significantly with healing of lesions and few fresh lesions. Pseudoporphyria has been associated with many medications including anti-inflammatory agents, antimicrobials and diuretics. Many cases of pseudoporphyria have been treated with $\mathrm{NAC}^{1}$ in conjunction with high-flux haemodialysis. ${ }^{2}{ }^{3}$ The mechanism of action of NAC is poorly understood but is felt to be related to an effect on 8-hydroxy-2'-deoxyguanosine ( $\mathrm{oh}^{8} \mathrm{dG}$ ) formation which has a role in free radical generation and subsequent tissue damage in association with 5-aminolevulinic acid which accumulates in porphyria. This diagnosis may be underrecognised in the renal population, and we suggest heightened awareness.

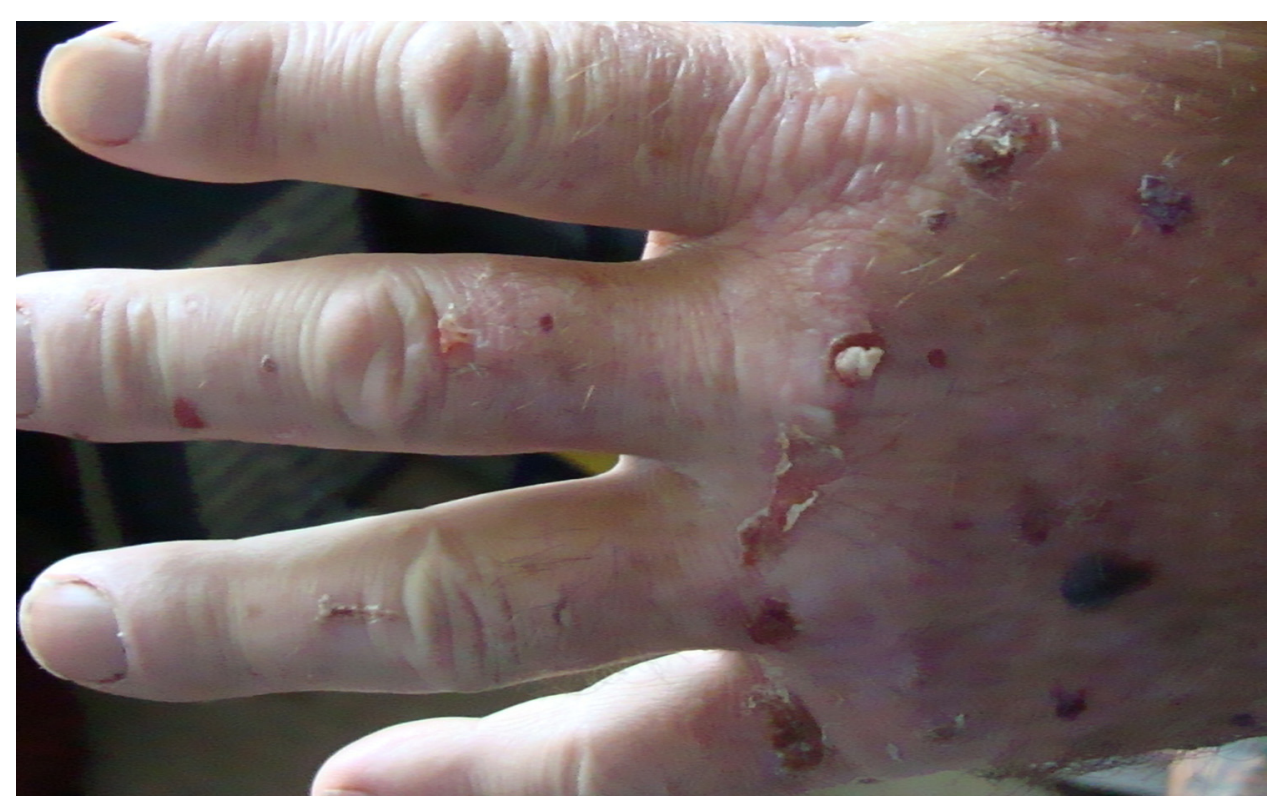

Figure 1 Multiple blistering lesions on dorsum of left hand at various stages of formation and rupture. 


\section{BMJ Case Reports}

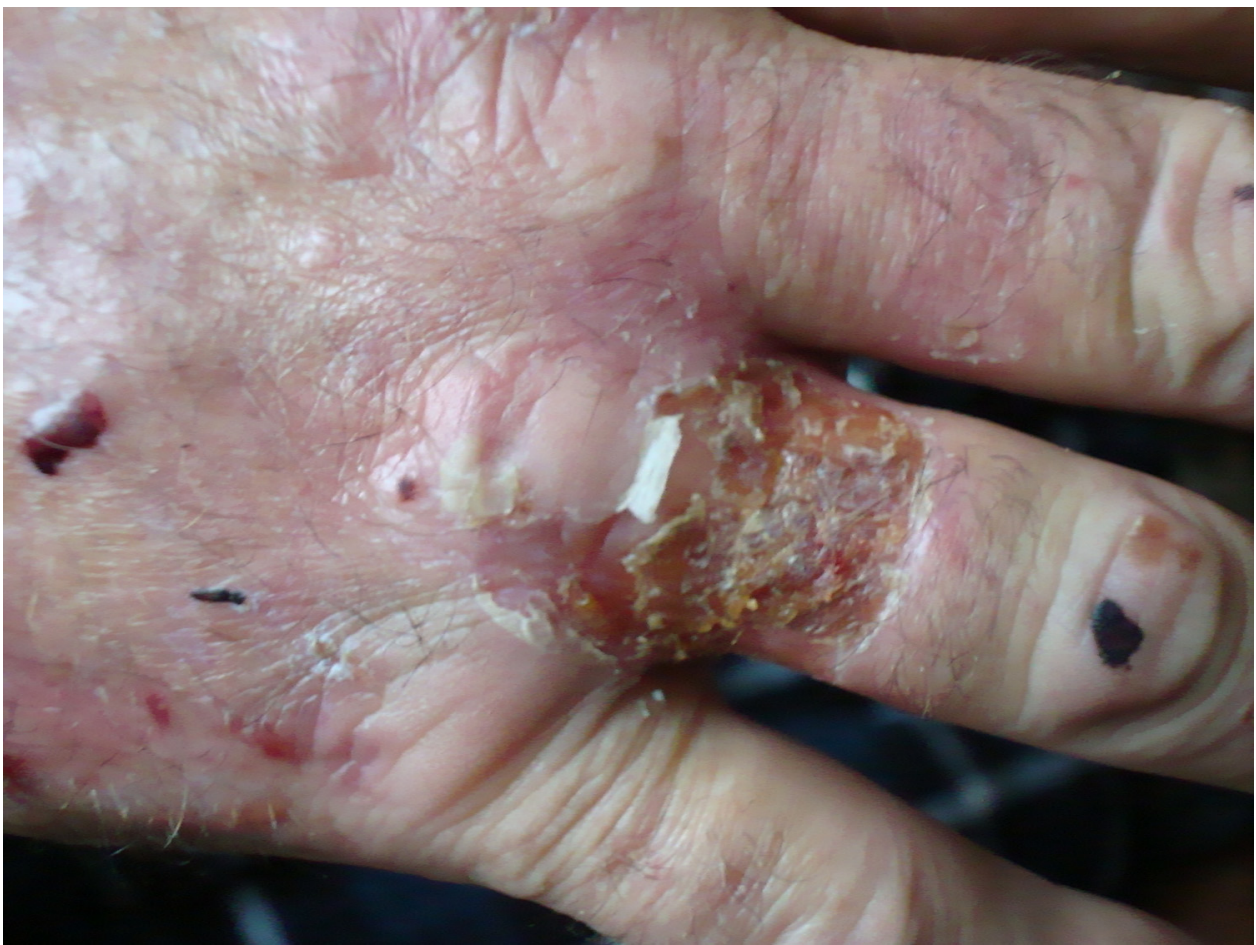

Figure 2 Large ruptured infection blister on dorsum of right hand.

\section{Competing interests None}

Patient consent Obtained.

\section{REFERENCES}

1. Cooke NS, McKenna K. A case of haemodialysis-associated pseudoporphyria successfully treated with oral $\mathrm{N}$-acetylcysteine. Clin Exp Dermatol 2007;32:64-6.
2. Massone C, Ambros-Rudolph CM, Di Stefani A, et al. Successful outcome of haemodialysis-induced pseudoporphyria after short-term oral N-acetylcysteine and switch to high-flux technique dialysis. Acta Derm Venereo 2006;86:538-40.

3. Tremblay JF, Veilleux B. Pseudoporphyria associated with hemodialysis treated with N-acetylcysteine. J Am Acad Dermatol 2003;49:1189-90.

This pdf has been created automatically from the final edited text and images.

Copyright 2010 BMJ Publishing Group. All rights reserved. For permission to reuse any of this content visit http://group.bmj.com/group/rights-licensing/permissions.

BMJ Case Report Fellows may re-use this article for personal use and teaching without any further permission.

Please cite this article as follows (you will need to access the article online to obtain the date of publication)

Smyth A, Redahan L, Wall C, Mellotte GJ. Porphyria or not porphyria - that is the question.... BMJ Case Reports 2010;10.1136/bcr.12.2009.2574, date of publication

Become a Fellow of BMJ Case Reports today and you can:

- Submit as many cases as you like

- Enjoy fast sympathetic peer review and rapid publication of accepted articles

- Access all the published articles

- Re-use any of the published material for personal use and teaching without further permission

For information on Institutional Fellowships contact consortiasales@bmjgroup.com

Visit casereports.bmj.com for more articles like this and to become a Fellow 